TI 2011-107/3

Tinbergen Institute Discussion Paper

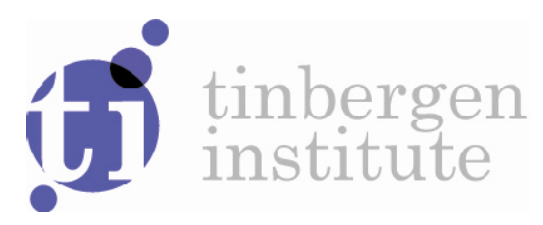

\title{
Institutional Capacity to Dynamically Innovate: \\ An Application to the Portuguese Case
}

Purificacíon Vicente Galindo'

Teresa de Noronha Vaz²

Peter Nijkamp3

\footnotetext{
1 University of Salamanca, Spain, and Centro de Investigação sobre o Espaço e as Organizações,

${ }^{2}$ Centro de Investigação sobre o Espaço e as Organizações, and University of the Algarve, Portugal;

${ }^{3}$ VU University, Amsterdam, the Netherlands, and Tinbergen Institute.
} 
Tinbergen Institute is the graduate school and research institute in economics of Erasmus University Rotterdam, the University of Amsterdam and VU University Amsterdam.

More TI discussion papers can be downloaded at http://www.tinbergen.nl

Tinbergen Institute has two locations:

Tinbergen Institute Amsterdam

Gustav Mahlerplein 117

1082 MS Amsterdam

The Netherlands

Tel.: +31(0)205251600

Tinbergen Institute Rotterdam

Burg. Oudlaan 50

3062 PA Rotterdam

The Netherlands

Tel.: +31(0)10 4088900

Fax: $+31(0) 104089031$

Duisenberg school of finance is a collaboration of the Dutch financial sector and universities, with the ambition to support innovative research and offer top quality academic education in core areas of finance.

DSF research papers can be downloaded at: http://www.dsf.nl/

Duisenberg school of finance

Gustav Mahlerplein 117

1082 MS Amsterdam

The Netherlands

Tel.: +31(0)20 5258579 


\title{
Institutional Capacity to Dynamically Innovate: An Application to the Portuguese Case
}

\author{
Purificacíon Vicente Galindo ${ }^{1}$, Teresa de Noronha Vaz ${ }^{2}$ and Peter Nijkamp ${ }^{3}$
}

\begin{abstract}
The present paper addresses the dynamics of innovation, by extending the analysis beyond a static-economic perspective. It offers a dynamic-institutional mapping of relational capacities to dynamically innovate. Its main goal is to contribute to the abovementioned research theme by presenting a new methodology able to pinpoint different trends in the relational capacities of institutions when they are innovative. Thereby, major characteristics in the networks of innovation are identified. This investigation uses an extended set of private institutions and public organizations located in Portugal, evaluated by their WebPage contents. To this data set a new combination of multivariate statistical methods is applied to detect group performances, to compare them, and to identify gradients of capacity to dynamically innovate. The results demonstrate that this method can provide extremely useful and tailor-made information for policy evaluation at regional or national levels.
\end{abstract}

Keywords: dynamic innovation, policy evaluation, knowledge circuit, regional innovation systems, logistic biplot, principal coordinates

\footnotetext{
${ }^{1}$ Department of Statistics, University of Salamanca, Spain and Centro de Investigação sobre o Espaço e as Organizações, purivic@yahoo.com

${ }^{2}$ Centro de Investigação sobre o Espaço e as Organizações and Faculty of Economics, University of the Algarve, Portugal, mtvaz@ualg.pt

3 VU University, Amsterdam, the Netherlands, pnijkamp@feweb.vu.nl
} 


\section{Introduction}

\section{Innovation and change}

The theory of economic growth has shown a remarkable revival in recent years. The emergence of endogenous growth theory, the rise in studies on the new economic geography, and the current popularity of urban creativity and cultural diversity concepts have prompted a worldwide interest in the driving forces and socio-economic impacts of innovation and entrepreneurship [1-3]. Innovation has been a critical parameter of human intelligence and cognitive ability from its earliest stages of development onwards, although it is only in recent history that it has been recognized as a significant driver of social and economic change. In [4-7] we find various prominent contributions to this view.

A crucial way to induce a process of socio-economic and technological change is to stimulate the continuous production of new products or processes while, at the same time, encouraging the adaptation of society to absorb them. This idea calls for a systematic attempt to combine new knowledge and creative consumption in an interactive model for innovation, which requires the capacity of economic agents and organizations to coordinate and manage appropriate knowledge assets and social cognitive mechanisms [8-10].

In this context, it is recognized that science, as an engine for knowledge creation, is just an initiating step in the process of innovation [11]. The authors unequivocally acknowledge the multi-player dimension of innovation and the wider institutional setting where distinct forms of learning take place. Furthermore, they argue that due to the plurality of knowledge sources that induce innovation-based growth, sufficient attention should be devoted to a better understanding of markets and organizations.

From this perspective, three levels of innovation analysis may be distinguished and used to improve our conceptual understanding of innovation and knowledge creation. These are: the micro-, meso- and macro-levels of a comprehensive systemic approach, as presented in the 'knowledge circuit' shown in Figure 1.

\section{Networks of innovation}

Over the years many studies have convincingly demonstrated that innovation is not 'manna from heaven', but critically depends on various contextual conditions (e.g. culture) and spatial-industrial organization (e.g. urban districts, social capital, networks). For example, in various studies [12-15] it is argued that, at cross-country level analyses, the presence or lack of innovation may "affect differential growth rates". In particular, an imitative or innovative modus operandi may explain different levels of 
development among countries or regions, such as the 'technology gap' or even the 'north-south' asymmetry. Thus, Schumpeter's observations on the tendency of innovations to cluster - in spite of the close link between innovation and economic growth - suggest that the use of innovation as an instrument of public policy in order to promote fast economic development may require more detailed attention. In this regard, [16] helps by pointing out the epistemological limitations and desirable research issues in this research field: cross-disciplinarity, undetermined causality, path dependency, pluralistic leadership, systemic approach.

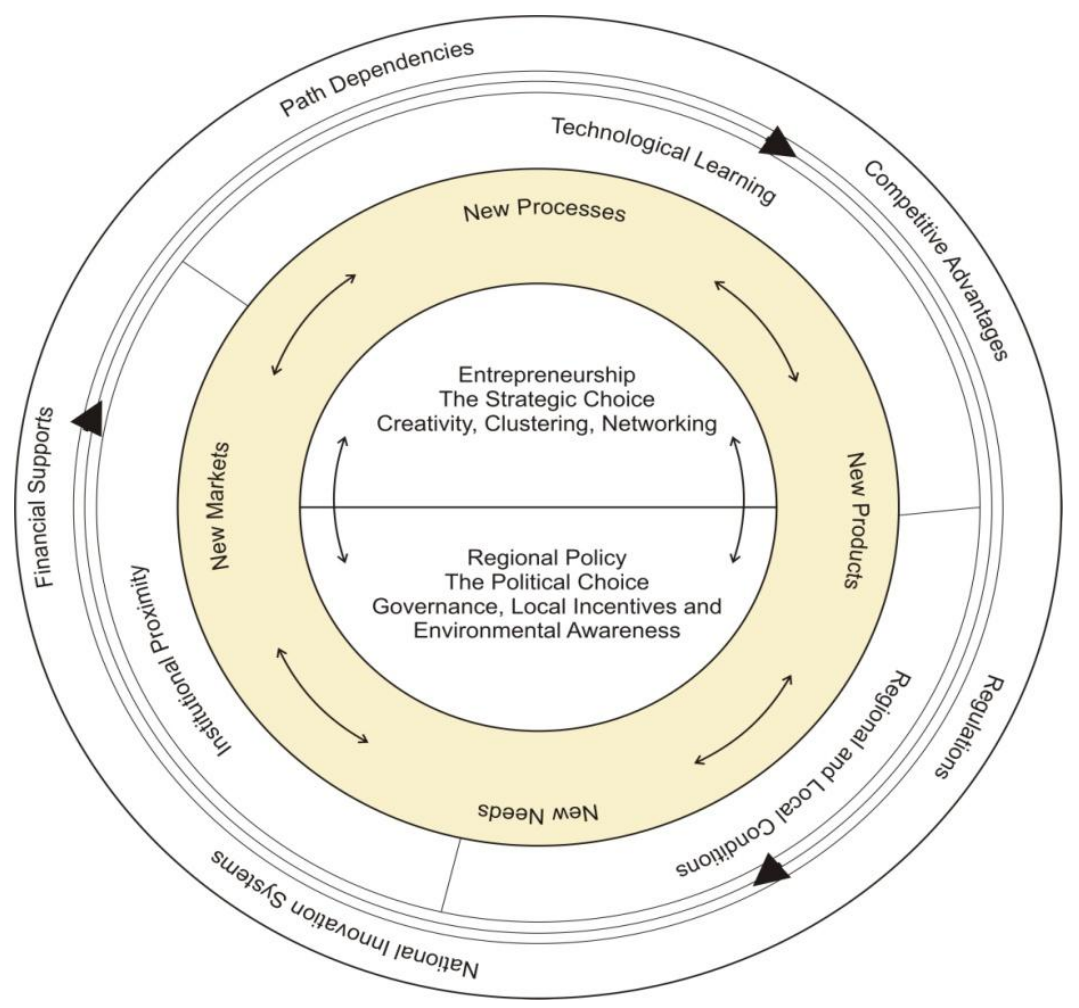

Figure 1. The knowledge circuit in the process of sustainable growth Source: [33]

The multiple efforts to better understand the drivers of innovation have stimulated researchers to adopt the resource-based view of the firm [17]. They have accepted the heterogeneous character of firms and their unique choices related to strategic behaviour [18]. In this context, knowledge is recognized as a key resource for firms and other economic agents, while both codified knowledge and tacit knowledge are pertinent aspects of innovativeness [19-20]. In addition, some authors have stressed the key role of 'good communication' between industry and research institutes for the successful transfer of technological knowledge [21]. An interesting extension of this literature can be found in the Triple Helix concept, whereby the triangular interaction between the research community, governments and industries is seen as key to 
successful innovation [22]. In [23,p.250] it is explained how "knowledge is socially embedded, created, and reproduced through social interaction".

Another strand of literature addresses in particular the growth potential offered by networks and industrial clusters. In effect, a great variety of studies on clustering has been instrumental in describing how - though not so much why - organizations and institutions get together to face and respond to competitive challenges [24]. A few attempts, however, can be found that explain why people from different entities join efforts to collaborate. [25], for example, explains that a cluster offers an environment for the development of a common language, social bonds, norms, and values, i.e. social capital. [26] adopts a deeper view, and tries to understand the cognitive reasons behind the existence of a cluster; see also [27-28]. They explain that, in a cluster, managers and decision makers share a great number of values, cognitive references, perceptions, and experiences (called normative isomorphism), and hence they tend to establish connections and follow the same patterns of organizational behaviour (e.g. competing, collaborating, and so on). Furthermore, there may also exist negative consequences of such isomorphism: since all these actors share a particular culture and a set of beliefs, there is a risk of strategic myopia, which reinforces imitator and non-innovative behaviour.

Despite an abundance of literature on this issue, there is still some confusion on the concepts of networking and clustering. For example, [29] argues that, while the term cluster is widespread, there is, however, no single universal definition. "We define a cluster as a spatial agglomeration of similar and related economic and knowledge creating activities". To enrich the debate on spatial clustering phenomena, the concept of Regional Innovation Systems (RIS) has been defined as "a network of organizations, institutions and individuals, within which, the creation, dissemination, and exploitation of new knowledge and innovation occurs" [30]. The RIS concept has been introduced to describe how the industrial and institutional structure of a given national or regional economy tends to steer technological and industrial development into certain trajectories. The link between 'clusters' and 'regional innovation systems' is that, within these spatial systems, groups of similar and related firms (e.g. large and small firms, suppliers, service providers, customers, rivals, etc.) comprise the core of the cluster, while academic and research organizations, policy institutions, government authorities, financial actors and various institutions for collaboration and networks make up the innovation system of which the cluster is a part [31].

The first aim of our paper is to integrate the elements of this complex context, in which many unresolved problems still demand due attention. This is the case for many shared practices that form national or regional patterns of interaction between 
innovation institutions; frequently, they provide the basis for the dissemination of knowledge which promotes innovations further. Analyses of the dynamics of innovation are, in this case, confined to the measurement level of the economic system. The next and most important aim of the present paper is to develop an operational methodology that is able to identify the different relational capacities of institutions when they are innovative. This can be done by searching the networks of innovation for their major characteristics that sustain continuous movement towards innovation. In our analytical framework, various new quantitative exploratory methods will be used (in particular, Principal Coordinates Analysis in combination with a Logistic Biplot method). This approach will then be applied to identify the drivers of the Portuguese innovation system.

\section{The Portuguese institutional innovation system}

Our study will take Portugal as a case study, a country where innovation is regarded as a key element for international competitiveness. The Portuguese Government, in office since March 2005, has had as its main policy a Technological Plan, and, as part of its commitment to fulfil the Lisbon strategy (renewed in an Integrated Plan), the PNACES (Plano Nacional de Acção para o Crescimento e Emprego 2005-8). This Plan had, as one of its main goals, the ambition "to increase the competitiveness of Portuguese economy" by implementing the new developments in information and communication technologies. The main question today is how successful this strategy has been. A further justification is provided by the Strategies for Collective Efficiency (2009) based on Clusters and the Economic Valorization of Endogenous Resources (http://www.pofc.qren.pt/PresentationLayer/ conteudo.aspx?menuid=457).

It is increasingly realized that the management of knowledge transfer does not only concern academic and research organizations, but also, and essentially, decision makers, financial actors, and large and small institutions eager to promote innovation. Awareness has grown that an improved understanding of how this knowledge transfer takes place will enable the innovation actors to overcome many obstacles and several challenges while facilitating their ability to create and sustain knowledge-based competitive advantages.

In Portugal, over the past decades a significant effort has been made to give continuous priority to people and knowledge to promote a networking of institutional systems. In particular, this was stressed for the scientific and tertiary Portuguese education system. This strategic governmental task was based on three main drivers: (i) the view that innovation should be considered together with competence building 
and advanced training at individual skill levels; (ii) the need for expanding the social basis for knowledge activities; and finally, (iii) the intensification of social networks to enhance the mobility of users to facilitate innovation diffusion. The country experienced the highest growth rate in Europe in private R\&D expenditures between 2005 and 2008, jumping from $0.3 \%$ of GDP in 2005 to $0.8 \%$ of GDP in 2008, which is a surprising performance [32]. Thus, the relevance of the current study on the Portuguese knowledge and innovation system is certainly warranted.

Our investigation uses an extended set of private institutions and public organizations located in Portugal, which are evaluated by their WebPage contents. On the basis of this data set, a new combination of multivariate statistical methods will be employed to detect group performances, to compare them, and to identify gradients of capacity to dynamically innovate. The results demonstrate that this method can provide useful information for policy evaluation of innovation systems at, both, regional or national levels.

For our investigation we have considered the following actors of innovation:

- Governmental agencies: all entities which pertain to the sphere of governmental power, and which exercise regulatory functions in political terms, as far as innovation is concerned. Furthermore, they play an important role in the promotion, administration, financing, and evaluation of creativity and innovation processes in the country.

- Associations: this category includes all agencies with a legal status which, depending on the interests of their associates, influence creativity and innovation. Examples of the activities of such associative entities include: sectoral or regional cooperation, knowledge transfer management, support to value creation (e.g. certification), regional partnerships.

- Technological parks and science centres: in this category one can find institutions which offer technical, technological or other type of support to organizations in the same economic or industrial sector. These entities contribute to creativity and innovation processes in numerous ways: technology transfer, partnerships, and certification.

- R\&D organizations: organizations which direct their main activities to R\&D, and which concentrate on broad economic and industrial applications (this category does not include private and public institutions whose main activity is not $R \& D$, though such institutions may have large investments in R\&D activities).

- Entrepreneurship support entities: this category refers to institutions or organizations which aim to stimulate creative and entrepreneurship activity. 
- Technological schools: these are concerned with entities which aim to provide technological and professional training and education in innovation-related areas.

- University interfaces: these include structures, units, or university associations, operating in a particular university, and which aim to act as an interface between the university and private and public institutions.

- Institutions: these are public and private organizations involved in innovation and/or with investments in innovation activity. Financial institutes as well as venture capitalists or high risk investors have also been classified in this category.

- Others: these are other entities with a role in creativity and innovation and which have not been included in any of the previous categories.

Data have been collected by means of a careful observation and inspection of 820 Internet sites of Portuguese institutions, classified into the aforementioned groups of actors. These sites have been found by means of a random choice of a sample including all the organizational sites presenting the following crossed keywords: inovação, inovador and inovada/do on their sites. The sample was gathered during the year 2006. Finally, after a screening, the cleaned database comprised 623 institutions, classified into the above nine groups (18 governmental entities, 297 private institutions, 70 associations, 20 technological parks and centres, 58 R\&D organizations, 48 entrepreneurship support entities, 12 technological schools, 80 university interfaces, and 14 other entities) and characterized by ten variables. The selection of these variables was based on our prior theoretical framework which suggests that the considered variables will likely determine innovation patterns - or, to be more specific, the firms' capacity to dynamically innovate [17] [33]. These ten variables are: Promoting knowledge (PK); Studying processes (SP); Managing (Mg); Promoting R\&D (PRD); Transferring knowledge (KT); Supporting entrepreneurship (SE); Developing new products (NPD); Promoting partnership and cooperation (PPC); Using external technologies (AET); and Specific orientation towards innovativeness $(\mathrm{OR})^{4}$. This database was then investigated in depth using the methodology presented next, in Section 3.

\footnotetext{
${ }^{4}$ For the analysis, innovation inputs and innovation outcomes have not been duly disaggregated. For the application of the methodology the eventual causal relationship is not of particular relevance.
} 


\section{Methodology and interpretation rules}

The information used in our analysis was organized in an $I x J$ binary data matrix $(Y)$ in which the I rows correspond to the above-mentioned 623 units and the $J$ columns correspond to the above-mentioned 10 binary innovation characteristics scored as binary variables, viz. present or absent (1 or 0 ).

As a means to obtain the main innovation gradients, of the entities and their relation to the observed characteristics, we apply a novel algorithm, recently proposed by [34], that combines Principal Coordinates Analysis (PCoA) and Logistic Regression (LR) to construct an External Logistic Biplot (ELB).

The algorithm starts with a PCoA, as a technique for ordering the entities in a Euclidean space. In this Euclidean map, units are represented as points. The dimensions of the PCoA solution can be considered as innovation factors or innovation gradients in a similar way as in Factor Analysis for continuous data [35]. This technique tends to cluster together the units with similar innovation profiles. In PCoA, the axes have no direct meaning; therefore it is not possible to interpret the relationship between units and variables. ELB enables the variables to be represented on the PCoA map.

To search for the variables associated with the ordering obtained in PCoA, we look for the directions in the ordering diagram that better predict the probability of the presence of each unit. So, the second step of the algorithm is adjusting a logistic regression model for each variable by using the latent gradients as independent variables. According to the geometry of the linear biplot for binary data [36], in which the responses along the dimensions are logistic (Logistic Biplots, LB), each variable is represented as a direction through the origin. In short, the next diagram (Figure 2) supplies a summary of the consecutive steps including the outcomes resulting from the methodological application. 


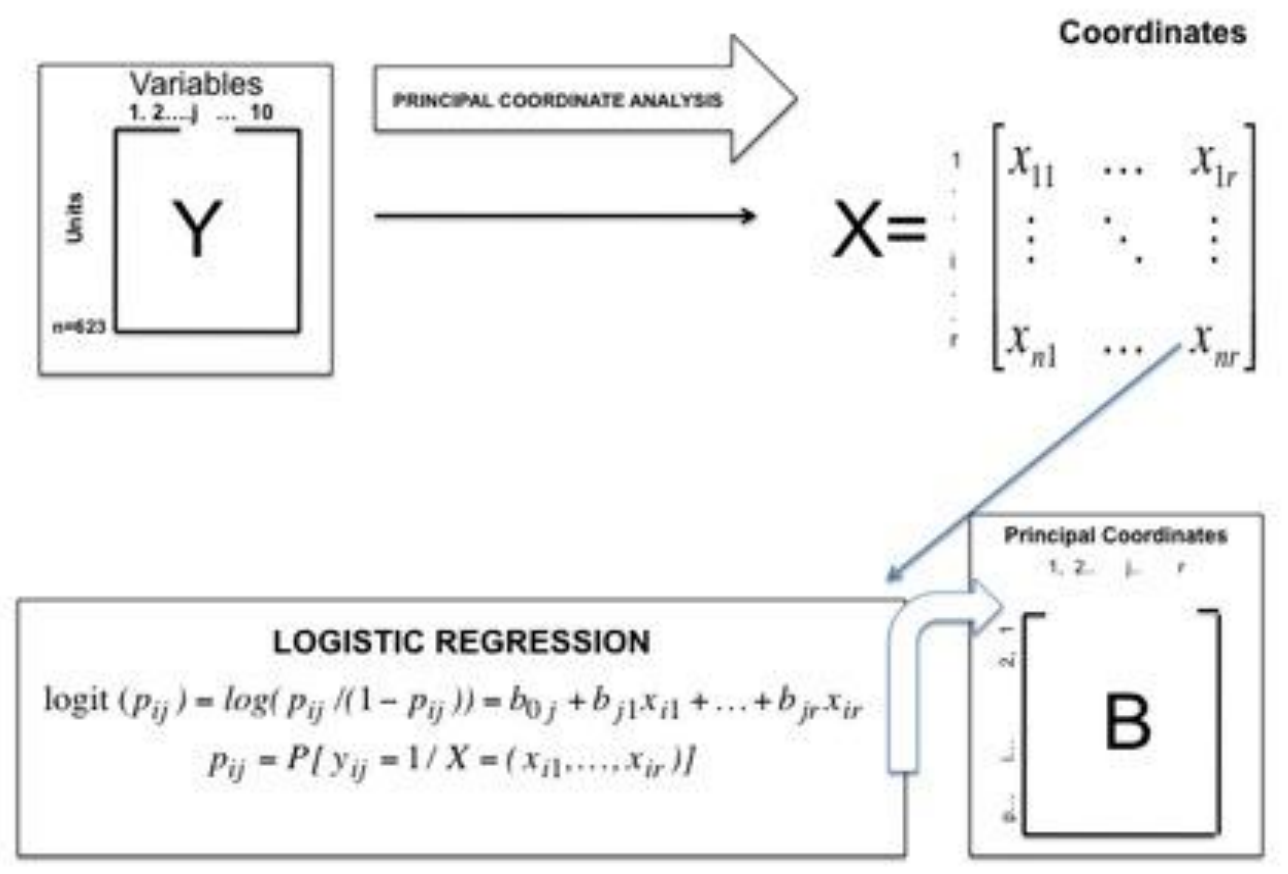

Figure 2. Steps for External Logistic Biplot. Y: data matrix, X: Principal Coordinates Matrix, B: Logistic Regression Coefficient Matrix.

The algorithm starts with a PCoA, as a technique for ordering the units, in a Euclidean space, on the latent gradients. The second step of the algorithm is adjusting a logistic regression model for each variable by using the latent gradients as independent variables. Geometrically the principal coordinates' scores can be represented as points in the map and the regression coefficients are the vectors showing the directions that best predict the probability of presence of each character.

For each character, the ordination diagram can be subdivided into two separate regions predicting presence or absence, while the two regions are separated by the line that is perpendicular to the character vector in the Biplot and cuts the vector at the point predicting 0.5 (for more details see also Figure 4). The characters associated with the configuration are those that predict the respective presences adequately.

Measures of the quality of the representation of units, and variables on the graphical representation are also calculated in this framework. The quality of representation of a unit is measured as the percentage of its variability accounted by the reduced dimension solution, and it is calculated as the squared cosine of the angle between the point/vector in the multidimensional space and its projection onto the low dimensional solution. As the representation is centered at the origin, the variability of each unit is measured by its squared distance to the centre, so that the quality of 
representation can be measured by the ratio between the squared distance in the reduced dimension and the squared distance in the complete space. The quality of representation of a variable is measured as a combination of three indexes: the p-value of the logistic regression, in order to test the relation of the solution and each variable (using the deviance); the Nagelkerke R squared; and the percentage of correct classifications, using 0.5 as a cut-off point for the expected probability. As a way to identify which gradient (dimension) is most related to each variable, the cosine of the angle of the vector representing the variable and the dimension is calculated. The variable is more related to a particular gradient when the absolute value of the cosine is higher than the cosine for other gradients. A computer program, based on Matlab code, for implementing these methods is available and can be obtained from the website: http://biplot.usal.es.

\section{Empirical results}

The Principal Coordinates Analysis is developed over the dissimilarities matrix, also called distance matrix, which describes the pairwise distinction between $M$ objects. This is a square symmetrical MxM matrix with the (ij)th element equal to the value of a chosen measure of distinction between the (i)th and the (j)th object. The diagonal elements are either not considered or are usually equal to zero - i.e. the distinction between an object and itself is postulated as zero. A closely related - and opposite concept is the similarity matrix. Both types of description are often used for the same data.

Any reasonable measure of dissimilarity may be used, including subjective scores of dissimilarity. The only requirement is that the greater distinction between two objects, the greater the value the measure of dissimilarity. As far as the dissimilarity matrix is specified, a corresponding similarity matrix can be calculated.

In our study the Principal Coordinates Analysis was developed over the dissimilarities matrix, based on the Russel and Rao coefficient, and has produced the following results (see Table 1):

Table 1. Eigenvalues, percentage of accounted variance

\begin{tabular}{|c|c|c|}
\hline 37.49 & 57.99 & 57.99 \\
\hline Eigenvalue & \% of variance & Cumulative \% \\
\hline 6.78 & 10.49 & 68.49 \\
\hline 5.85 & 9.05 & 77.53 \\
\hline
\end{tabular}


The inertia first principal plane (two-dimensional solutions) accounts for 68.49 per cent of the variability (Table 1). The first eigenvalue is significantly higher than the second one, meaning that, even if the two innovation gradients are considered, the first (horizontal) dimension accounts for most of the information.

In Figure 3 (see Appendix 2) (ELB map) below, we can observe a complex representation of the main patterns to dynamically innovate according to the ten considered variables: Promoting knowledge (PK); Studying processes (SP); Managing (Mg); Promoting R\&D (PRD); Transferring knowledge (KT); Supporting entrepreneurship (SE); Developing new products (NPD); Promoting partnership and cooperation (PPC); Using external technologies (AET); and Specific orientation towards innovativeness (OR). Each company profile has a particular location on the graph. The distance between any two company-points of the configuration approximates, as closely as possible, the dissimilarity between them.

The global goodness of fit as a percentage of correct classifications in the Biplot is 90.43 per cent. The goodness of fit (quality of representation) indexes for each variable is shown in Table 2. All R-squared values are higher than 0.6 , and therefore all variables are closely related to the two-dimensional PCoA solution.

Figure 4 (see Appendix 3) shows an illustrative biplot representation for one variable, "New Product development". Of course, similar interpretations can be provided for any other variable. The small arrow is the graphical representation of that variable on the biplot and shows the direction in the space spanned by the first two dimensions that better predicts the expected probabilities by projecting each unit (circles in the graph) onto that direction. All the points in the graph predicting the same probability lie on a straight line perpendicular to the prediction direction. In the graph, we have identified the lines predicting 0.5 and 0.75 . The first is important because it splits the map of points into two areas: the area predicting presence $\left(\pi_{i j}>0.5\right)$ and the area predicting absence $\left(\pi_{i j}<0.5\right)$.

Next, Table 3 contains the cosines of the angles of the variables with the dimensions. It has to be pointed out that any direction in the two-dimensional solution, and not just the main dimensions, can be considered as innovation gradients. The graph can help us to look for the most interpretable directions.

Table 2. Goodness-of-fit of the variables 


\begin{tabular}{|l|c|c|c|c|}
\hline Variable & Deviance & $p$-value & $R^{2}$ & $\%$ Correct \\
\hline Promoting knowledge & 674.94 & $<0.0001$ & 0.88 & 93.42 \\
\hline Studying process & 418.70 & $<0.0001$ & 0.68 & 82.50 \\
\hline Managing & 906.68 & $<0.0001$ & 0.92 & 92.29 \\
\hline R\&D & 549.93 & $<0.0001$ & 0.77 & 89.08 \\
\hline Knowledge transfer & 763.53 & $<0.0001$ & 0.90 & 92.67 \\
\hline Support to enterpreneurship & 267.13 & $<0.0001$ & 0.60 & 90.69 \\
\hline New product development & 723.74 & $<0.0001$ & 0.94 & 97.27 \\
\hline Promoting partnership \& cooperation & 733.39 & $<0.0001$ & 0.92 & 95.19 \\
\hline Application of external tecnologies & 822.17 & $<0.0001$ & 0.93 & 95.02 \\
\hline Orientation & 544.62 & $<0.0001$ & 0.77 & 83.95 \\
\hline
\end{tabular}

An analysis of the cosines' value in the graph identifies two main directions for innovation gradients. A third column has been added to Table 3 showing which variables are most related to each direction. The first gradient is almost parallel to dimension 1 (horizontal) and the second to dimension 2 (vertical). Although the variable 'Promoting knowledge' has a higher cosine with the first dimension, it has been assigned to the second gradient after inspecting the graph.

Table 3. Cosines of the angles

\begin{tabular}{|l|r|r|c|}
\hline Variable & $1^{\text {st }}$ grad. & $2^{\text {nd }}$ grad. & Associated grad. \\
\hline Promoting knowledge & 0.96 & 0.28 & 1 \\
\hline Studying process & -0.87 & 0.49 & 2 \\
\hline Managing & -0.98 & -0.20 & 1 \\
\hline R\&D & -0.94 & -0.35 & 1 \\
\hline Knowledge transfer & -0.96 & -0.27 & 1 \\
\hline Support to entrepreneurship & -0.31 & -0.95 & 2 \\
\hline New product development & -0.35 & 0.94 & 2 \\
\hline Promoting partnership \& cooperation & -0.75 & -0.66 & 1 \\
\hline Application of external technologies & -0.40 & 0.92 & 2 \\
\hline Orientation & -0.95 & -0.31 & 1 \\
\hline
\end{tabular}

From the graph and the quality indexes, we can conclude that the first innovation gradient is mainly given by a combination of the following variables: Promoting knowledge (PK); Managing (Mg); Promoting R\&D (PRD); Transferring knowledge (KT); Promoting partnership and cooperation (PPC); Specific orientation towards innovativeness (OR).

Observing the directions of the vectors relative to the first latent attribute, it can be concluded that the presence of all those characteristics tend to show up together (as we hypothesized in the Introduction), and that the entities (institutions) positioned on the left side of the graph have a higher capacity to dynamically innovate, because they tend to aggregate higher values of those variables (characteristics), while the 
entities (institutions) positioned on the right side lack most of such characteristics. As such, this measurement may be interpreted as a complex innovation index, defined here by us as the Gradient of Capacity to Dynamically Innovate (GCDI). As a contribution to the results of our investigation the institutions were ranked according to this gradient, so that those mostly advantageous could be identified. Because the study is dealing with 623 different institutions, and many of them have the same combination of characteristics it is impossible to visualize all of them on the two-dimensional space generated by the first two innovation gradients. Would zooming be possible at a three dimensional scale, this visualization could be done. The complete set of the most innovative institutions according to GCDI is presented in Appendix 1. Using this same method, the scores of the variables on the first gradient can be ordered to obtain the sequence of characteristics that define the degree of innovation. The most innovative institutions have the total number of characteristics, and then they are followed by those entities that have all of them, except Promoting R\&D (PRD) whose score is situated to the left of the graph. The next group would have all the characteristics related to the gradient, except Promoting $R \& D(P R D)$ and Managing (Mg), and so on.

The second innovation gradient is a combination of Studying process (SP); New product development (NPD); Application of external technologies (AET) pointing in the positive direction; and Support to entrepreneurship (SE) pointing in the opposite direction.

This secondary gradient is not correlated with the first one and summarizes an aspect of innovation independent from the main dynamic pattern. The institutions situated on the top of the graph would combine the first three characteristics pointed out previously and the last would be absent, while the institutions situated at the bottom would have the last one with an absence of the first three characteristics pointed out previously.

The graphical representation corroborates the interpretation of the innovation gradients in terms of their relations to the variables. It can also be concluded from the graph that there is a high correlation between Promoting knowledge, Studying processes, Managing, Promoting R\&D, Knowledge transfer and Orientation. This is because they have small angles pointing in the same direction. 


\section{Conclusions}

Indeed, the Logistic Biplot technique is considered to be the representation of a set of complex measures onto a two-dimensional plane by reducing the overall data variance to a couple of dimensions that are difficult to interpret from economic facts [37]. On the other hand, however, representation of complexity may ease interpretation and suggest more reliable solutions, as we can see in the case of the institutional capacity to innovate.

From the application of the Logistic Biplot methodology to the institutional databases we were able to demonstrate that institutions are very diverse in the way they combine determinants for their patterns towards the dynamics of innovation - the two-dimensional PCoA solution accounts for the main interpretation of the variation patterns related to the data used. The dimensions of the solution can be interpreted as innovation gradients, useful to classify the entities according to their "degree of complex characteristics leading to dynamic innovation".

The gradients summarize the information common to several variables, and identify subsets of variables that tend to cluster together. Considering the relation of the variables to the innovation gradient of capacity to dynamically innovate, we are able to conclude that the determinants 'Promoting knowledge', 'Managing', 'Promoting R\&D', 'Transferring knowledge', 'Promoting partnership \& cooperation' and 'Orientation', are the most influential ones.

It was also possible to create a ranking of those institutions that have a higher gradient of capacity to dynamically innovate. And such a ranking can be carefully observed in the management profile of institutions - a task not yet developed in this study, but a challenging one for further investigation.

Clearly, we may also identify further single characteristics from the ranking list, if one is able to observe the institutional profile in the respective site duly addressed in Annex 1. But, the great challenge of our paper relies on its methodological approach which combines simultaneously Principal Coordinates Analysis (PCoA), Logistic Regression (LR), and External Logistic Biplots. The method, as demonstrated in this publication, leads the way to classify and identify innovation from an inter-relational, multi-vectorial and more systemic perspective. A more dynamic point of view, suggesting that innovation is influenced by many determinants of active functioning, is implied by this method, allowing the existence of a heterodox innovation measure.

By detecting the relational structure of innovative firms and public institutions in Portugal, many advantages and fragilities in the firms' capacity to cooperate may be 
identified and clearly interpreted; and, moreover, their cooperative patterns (networks) can be examined. Such a major goal represents a step forward into governance structures. Seen from a meso-economic level, the eventual dynamic changes of such structures can be traced for the future as a tool for tailor-made policy-making, without much additional cost. Partnerships between actors may be evaluated, and their added value for innovativeness may be reviewed as well.

Finally, this study may serve as a useful instrument to evaluate eventual losses in the optimal rate of R\&D investment to maximize productivity growth, as pointed out by Coccia (2009). The author justifies the diminishing returns to R\&D investments on the grounds of the particularities of the inner institutional configuration, a phenomenon that may be better understood by using the above described methodology. Clearly, more indepth research is still needed, e.g. by looking into the regional dimensions of $R \& D$ and the personal motivations of R\&D agents.

\section{Acknowledgements}

The Portuguese Foundation for Science and Technology has financed part of the research presented in this paper.

\section{References}

[1] P.Nijkamp, (2009a). "E Pluribus Unum", Region Direct (forthcoming).

[2] P. Nijkamp,(2009b). "Regional Development as Self-Organized Converging Growth", in: G. Kochendorfer and B. Pleskovic (eds.), Spatial Disparities and Development Policy. The World Bank, Washington DC, pp. 205-282.

[3] R. Stimson, R. Stough and B.H. Roberts (2006). Regional Economic Development, Springer, Berlin.

[4] J. Schumpeter, (1934). The Theory of Economic Development, Harvard University Press, Harvard.

[5] J. Schumpeter, (1954). History and Economic Analysis, Allen \& Unwin, New York.

[6] C. Freeman, (1987). Technology Policy and Economic Performance: Lessons from Japan, Printer, London.

[7] J. Fagerberg, (2003). "Schumpeter and the Revival of Evolutionary Economics: an Appraisal of the Literature", Journal of Evolutionary Economics 13: 125-59.

[8] R. Hall, and M. Wee (1995). "The Regions in a Enlarged Europe", in: S. Hardy, M. Hart, L. Albrechts and A. Katos (eds.), An Enlarged Europe. Regions in Competition? Regional Policy and Development, 6. Jessica Kingsley Publishers, London. pp.8-21.

[9] B.A. Lundvall, (1988). "Innovation as an Interactive Process", in: G. Dosi, C. Freeman, R. Nelson and G. Silverberg, Technical Change and Economic Theory, Ifias Research Series, Number 6, Pinter Publishers, New York, pp. 349-369.

[10] B.A. Lundvall, (1992). "Introduction" in B.A. Lundvall (ed.), National Systems of Innovation, Pinter, London, pp. 1-19.

[11] J.Caraça, B- $\AA$ Lundvall, and S.Mendonça, (2009). "The Changing Role of Science in the Innovation Process: From Queen to Cinderella?", Technological Forecasting \& Social Change 76: 861-867.

[12] M.V. Posner, (1961). "International Trade and the Technical Change". Oxford Economic Papers 13: 323-41.

[13] P. Krugman, (1979). "A Model of Innovation, Technology Transfer and the World Distribution of Income", Journal of Political Economy 87: 253-66.

[14] J. Fagerberg, (1987). "A Technology Gap Approach To Why Growth Rates Differ", 
Research Policy 16: 87-99.

[15] J. Fagerberg, (1988). "Why Growth Rates Differ", in: G. Dosi, C. Freeman, R. Nelson, G. Silverberg, and L. Soete (eds.), Technical Change and Economic Theory, Pinter, London, pp. 432-57.

[16] J. Fagerberg, (2004). "A Guide to the Literature", in: J. Fagerberg, D. Mowery, M.T. Terrill and R. Nelson (eds.), The Oxford Hand Book of Innovation, Oxford University Press, Oxford, pp. $1-26$.

[17] M.T.N. Vaz, and M. Cesario (2008). "Driving Forces for Innovation: Are They Measurable?", International Journal of Foresight and Innovation Policy 4(1-2): 30-50.

[18] A. Kaleka, (2002). "Resources and Capabilities Driving Competitive Advantage in Export Markets: Guidelines for Industrial Exporters", Industrial Marketing Management 31 (3): 273-283.

[19] V.A.C. Albino, Garavelli and G. Schiuma (1999). "Knowledge Transfer and Inter-firm Relationships, Industrial districts: The Role of the Leader Firm", Technovation 19 (1): 53-56. [20] B. Nooteboom, (1999). "Innovation and Inter-firm Linkages: New Implications for Policy", Research Policy, 28 (8): 793-805.

[21] U. Kaiser, (2002). "Measuring Knowledge Spillovers in Manufacturing and Services: An Empirical Assessment of Alternative Approaches", Research Policy 31 (1): 125-144.

[22] H. Etzkovitz, and L. Leydesdorff (1998). "The Triple Helix as a Model for Innovation Studies", Science and Public Policy 25(3): 195-203.

[23] D. Doloreux, (2002), "What We Should Know About Regional Systems of Innovation", Technology in Society 24: 243-263.

[24] M. Porter, (1998). "Clusters and the New Economics of Competition", Harvard Business Review, pp. 77-90.

[25] M. Porter, and O. Sölvell (1998). "The Role of Geography in the Process of Innovation and the Sustainable Competitive Advantage of Firms", in: D. Chandler Jr, P. Hagstrom and O. Sölvell (eds.), The Dynamic Firm: The Role of Technology, Strategy and Regions, Oxford University Press, Oxford, pp. 440-458.

[26] R. Ponder, and C. John (1996). "Hot Spots and Blind Spots: Geographical Clusters of Firms and Innovation", Academy of Management Review 21 (44): 1192-1225.

[27] H. Westlund, and R. Bolton (2006). "Local Social Capital and Entrepreneurship". Small Business Economics 21(2): 77-113.

[28] R. Putnam, (2000). Bowling Alone, Simon and Schuster, New York.

[29] R. Teigland and A. Schenkel (2005) "Exploring the Role of Communities of Practice in Regional Innovation Systems". In E. Coakes and S. Clarke (Eds.) The Encyclopedia of Communities of Practice in Information and Knowledge Management, London: Idea Group Inc.

[30] P.Cooke, H.J. Braczyk and M. Heidenreich M. (eds.) (2004). Regional Innovation Systems: The Role of Governances in a Globalized World, 2nd Edition, Routledge, London.

[31] R. Teigland, and A. Schenkel (2006). "Exploring the Role of Communities of Practice in Regional Innovation Systems", in: Coakes, E. and Clarke, S. (eds.), The Encyclopaedia of Communities of Practice, Idea Group, Hersley.

[32] M. Heitor, and Bravo, M. (2010). "Portugal at the Crossroads of Change, Facing the Shock of the New: People, Knowledge and Ideas Fostering the Social Fabric to Facilitate the Concentration of Knowledge Integrated Communities", Technological Forecasting \& Social Change 77: 218-247.

[33] M.T.N. Vaz, and P. Nijkamp (2009). "Knowledge and Innovation: The Strings Between Global and Local Dimensions of Sustainable Growth", Entrepreneurship and Regional Development, 21,(4):441-457.

[34] J.R. Demey, J.L. Vicente-Villardón, M.P. Galindo and A.Y. Zambrano (2008). "Identifying Molecular Markers Associated with Classifications of Genotypes by External Logistic Biplot", Bioinformatics 24: 2832.

[35] J. Monteiro-Barata, (2005). "Innovation in the Portuguese Manufacturing Industry: Analysis of a Longitudinal Company Panel", International Advances in Economic Research 11: 301-314. [36] J.L. Vincente-Villardon, M.P. Galindo-Villardon and A. Blazquez-Zaballos (2006). " Logistic Biplots", in. M. Greenacre and J. Blasius (eds.), Multiple correspondence analysis and related methods. Chapman Hall, Boca, Raton, FL, pp.503-521.

[37] M. Greenacre, and J. Blasius (2006). Multiple Correspondence Analysis and Related Methods. Chapman-Hall, Boca-Raton, FL. 
Purificacíon Vicente Galindo is assistant professor in statistics at the Department of Statistics, University of Salamanca. She is also an invited lecturer at the following universities: Unibe-Costa Rica, University of Veracruz-México and Orient UniversityVenezuela. She is a postdoctoral fellow member at the Research Center for Spatial and Organizational Dynamics, University of Algarve. Her research interests are closely related to data analyses.

Teresa de Noronha Vaz professor in economics of innovation at the University of Algarve and was visiting professor at Centre ATOM, Universite de Paris I, University of Gent, University of Oriel, University of Bologna and in Curitiba. She is the president of the Research Centre on Spatial and Organizational Dynamics. She has been coordinator of several European, national and local founded projects and edited several books related with regional/rural development and published an extensive amount of scientific material related to regional economics, public policies and the use of instruments to implement innovation in lagging areas.

Peter Nijkamp is professor in regional and urban economics and in economic geography at the VU University, Amsterdam. His main research interests cover quantitative plan evaluation, regional and urban modelling, multicriteria analysis, transport systems analysis, mathematical systems modelling, technological innovation, entrepreneurship, environmental and resource management and sustainable development. In the past years he has focussed on new quantitative methods for policy analysis and on spatialbehavioural analysis of economic agents. He is past president of the Netherlands Research Council (NWO). In 1996, he was awarded the most prestigious scientific prize in the Netherlands, the Spinoza award. 


\section{Appendix 1: Ranking of most innovative institutions according to the Gradient of Capacity to Dynamically Innovate}

\begin{tabular}{|c|c|c|c|}
\hline Code & Name of the institutions & Site & $\begin{array}{c}\text { Type of } \\
\text { institution }\end{array}$ \\
\hline 120 & EUROPROTEA - Sociedade Agrícola, Lda & www.europrotea.pt & Private company \\
\hline 123 & F. Lima, S.A. & www.flima.pt & Private company \\
\hline 134 & GalpEnergia, S.A. & www.galpenergia.com/ & Private company \\
\hline 140 & Grupo Aitec & www.aitec.pt/ & Private company \\
\hline 143 & Grupo Cised & www.cised.pt/ & Private company \\
\hline 149 & Grupo Portucel/Soporcel & www.portucelsoporcel.com/ & Private company \\
\hline 420 & Instituto de Biologia Experimental e Tecnologia & www.ibet.pt/ & $\mathrm{R} \& \mathrm{D}$ \\
\hline 575 & $\begin{array}{l}\text { Instituto de Desenvolvimento e Inovação } \\
\text { Tecnológica do Minho - IDITE-Minho }\end{array}$ & www.idite-minho.pt & $\begin{array}{l}\text { University } \\
\text { extensions }\end{array}$ \\
\hline 23 & Adira - Máquinas - Ferramentas, Lda. & www.adira.pt/ & Private company \\
\hline 29 & All 2 IT - Infocomunicações, SA & www.all2it.pt/i & Private company \\
\hline 32 & Ao Sol - Energias Renováveis, Lda. & www.aosol.pt/ & Private company \\
\hline 51 & BIAL - Portela \& Cia, S.A. & www.bial.pt & Private company \\
\hline 53 & Biotecnol - Serviços e Desenvolvimento, S.A. & $\begin{array}{l}\text { http://www.cotecportugal.pt/index.php?o } \\
\text { ption=com_content\&task=view\&id=241 }\end{array}$ & Private company \\
\hline 54 & Biotempo - Biotechnology Consulting, Ltd. & www.biotempo.com & Private company \\
\hline 56 & Bluepharma - Indústria Farmacêutica, SA & www.bluepharma.pt/ & Private company \\
\hline 59 & $\begin{array}{l}\text { CADFORM - Design de Produto Assistido por } \\
\text { Computador e Fabrico de Protótipos, Lda }\end{array}$ & www.cadform.pt/ & Private company \\
\hline 65 & $\begin{array}{l}\text { CAVEX - Sociedade de Exportação-Importação, } \\
\text { Estudos e Planeamentos de Equipamentos Industriais }\end{array}$ & Www.cavexgroup.com/cavex & Private company \\
\hline 75 & CHIRON - Sistemas de Informação, Lda. & www.chiron.pt/ & Private company \\
\hline 77 & CIN - Corporação Industrial do Norte, S.A. & www.cin.pt/ & Private company \\
\hline 78 & $\begin{array}{l}\text { CIPAN - Companhia Industrial Produtora de } \\
\text { Antibióticos, S.A. }\end{array}$ & www.cipan.pt/ & Private company \\
\hline 93 & CTT - Correios de Portugal, AS & www.ctt.pt & Private company \\
\hline 96 & DEIMOS Engenharia, SA & www.deimos.pt/ & Private company \\
\hline 100 & $\begin{array}{l}\text { DURIT - Metalúrgica Portuguesa de Tungsténio, } \\
\text { Lda. }\end{array}$ & www.durit.pt/ & Private company \\
\hline 103 & ECBIO - Biotechnology Consultants & Www.ecbio.com & Private company \\
\hline 106 & $\begin{array}{l}\text { EDISOFT - Empresa de Serviços e Desenvolvimento } \\
\text { de Software, SA }\end{array}$ & www.edisoft.pt/ & Private company \\
\hline 109 & $\begin{array}{l}\text { EID- Empresa de Investigação e Desenvolvimento de } \\
\text { Electrónica, SA }\end{array}$ & www.eid.pt & Private company \\
\hline 125 & $\begin{array}{l}\text { FAPOMED - Indústria de Confecções de Produtos } \\
\text { Médico-Cirúrgicos, S.A. }\end{array}$ & www.fapomed.com/ & Private company \\
\hline 161 & IBM Portuguesa, SA & www.ibm.com/ibm/pt/ & Private company \\
\hline 166 & Innovagency & www.innovagency.com & Private company \\
\hline 221 & PETROGAL - Petróleos de Portugal, S. A. & Www.galpenergia.com & Private company \\
\hline 222 & Philips Portuguesa, S.A. & www.philips.pt & Private company \\
\hline 456 & INESC MN Microsistemas \& Nanotecnologias & www.inesc-mn.pt & $\mathrm{R} \& \mathrm{D}$ \\
\hline 528 & $\begin{array}{l}\text { Associação CCG/ZGDV - Centro de Computação } \\
\text { Gráfica }\end{array}$ & www.ccg.pt & $\begin{array}{l}\text { University } \\
\text { extensions }\end{array}$ \\
\hline 137 & Gesventure (capital de risco) & www.gesventure.pt/ & Private company \\
\hline 139 & $\begin{array}{l}\text { GLOBALGARVE- Cooperação e Desenvolvimento, } \\
\text { AS }\end{array}$ & www.globalgarve.pt/ & Private company \\
\hline 154 & Grupo Visabeira, SGPS, SA & www.grupovisabeira.pt & Private company \\
\hline 5 & FJ - Fundação da Juventude & www.fjuventude.pt & Government \\
\hline 585 & INESC Inovação - Instituto de Novas Tecnologias & www.inov.pt/ & Private company \\
\hline 90 & Critical Software, S. A. & www.criticalsoftware.com/ & Private company \\
\hline 376 & $\begin{array}{l}\text { RECET- Associação dos Centros Tecnológicos de } \\
\text { Portugal }\end{array}$ & www.recet.pt/ & Association \\
\hline 423 & $\begin{array}{l}\text { ICTPOL- Instituto de Ciência e Tecnologia de } \\
\text { Polímeros }\end{array}$ & www.ictpol.com/ & $\mathrm{R} \& \mathrm{D}$ \\
\hline 454 & LNEC Laboratório Nacional de Engenharia Civil & www-ext.lnec.pt/ & R\&D \\
\hline 459 & $\begin{array}{l}\text { ICBAS - Instituto de Ciências Biomédicas Abel } \\
\text { Salazar }\end{array}$ & http://sigarra.up.pt/icbas/web_page.inicial & R\&D \\
\hline 580 & INEB - Instituto Nacional de Engenharia Biomédica & www.ineb.up.pt & R\&D \\
\hline 70 & CENTRALCER - Central de Cervejas, S. A. & www.centralcervejas.pt/ & Private company \\
\hline
\end{tabular}


Appendix 2: Figure 3. Gradient of capacity to dynamically innovate.

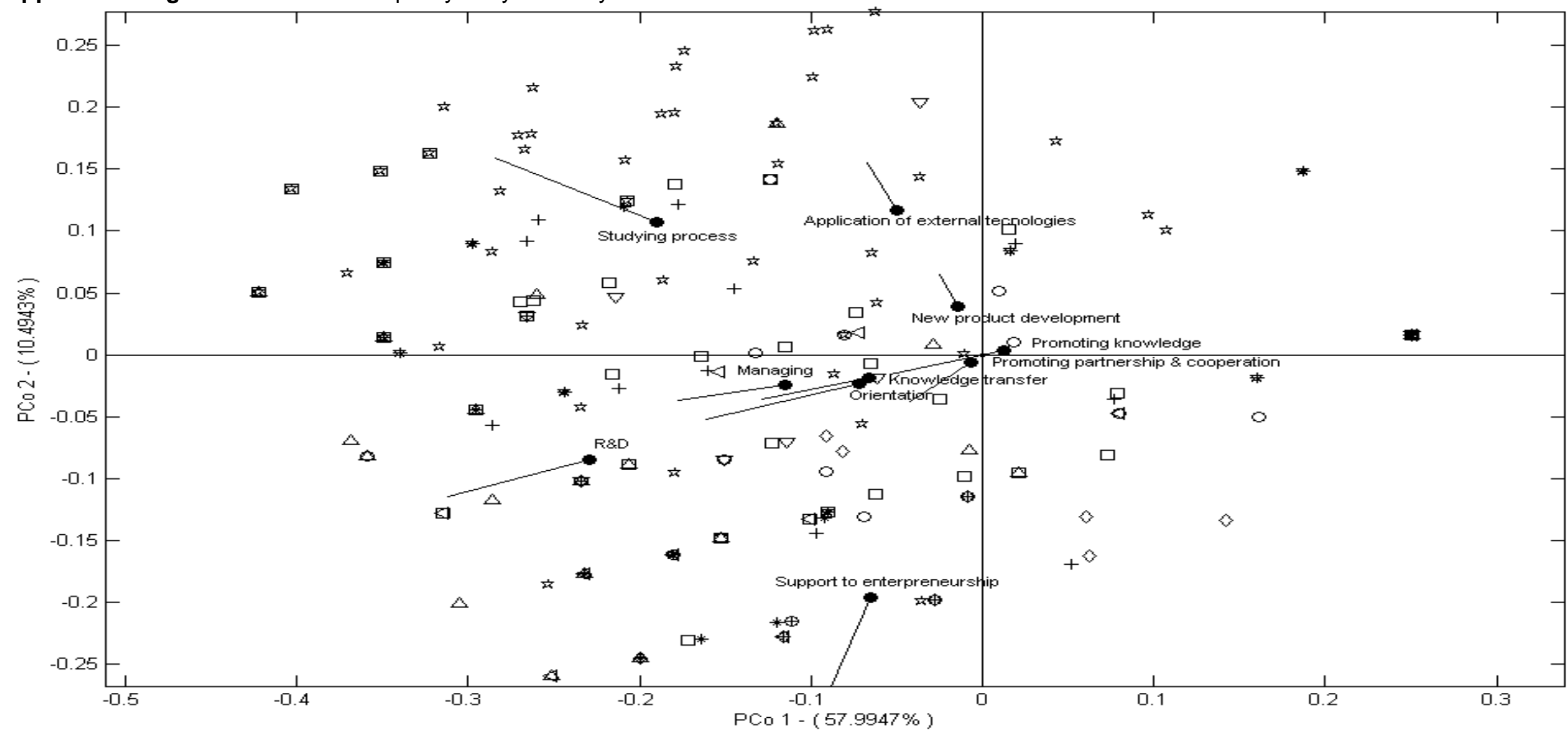

Each character is represented as a direction through the origin. The projection of a point representing a unit onto a character direction predicts the probability of the presence of that character, i.e. the expected probability of having that character for an entity with the same combination of variables (innovation profile). A vector joining the points for 0.5 and 0.75 is also drawn; this shows the cut-off point for the prediction of the presence and the direction of increasing probabilities. The length of the vector can be interpreted as an inverse measure of the highly correlated, while two characters pointing in opposite directions are negatively correlated, and two characters forming an angle close to $90^{\circ}$ are almost uncorrelated. The variability of each unit is measured by its squared distance to the centre. 
Appendix 3: Figure 4. Interpretation of the relationship between units and variables.

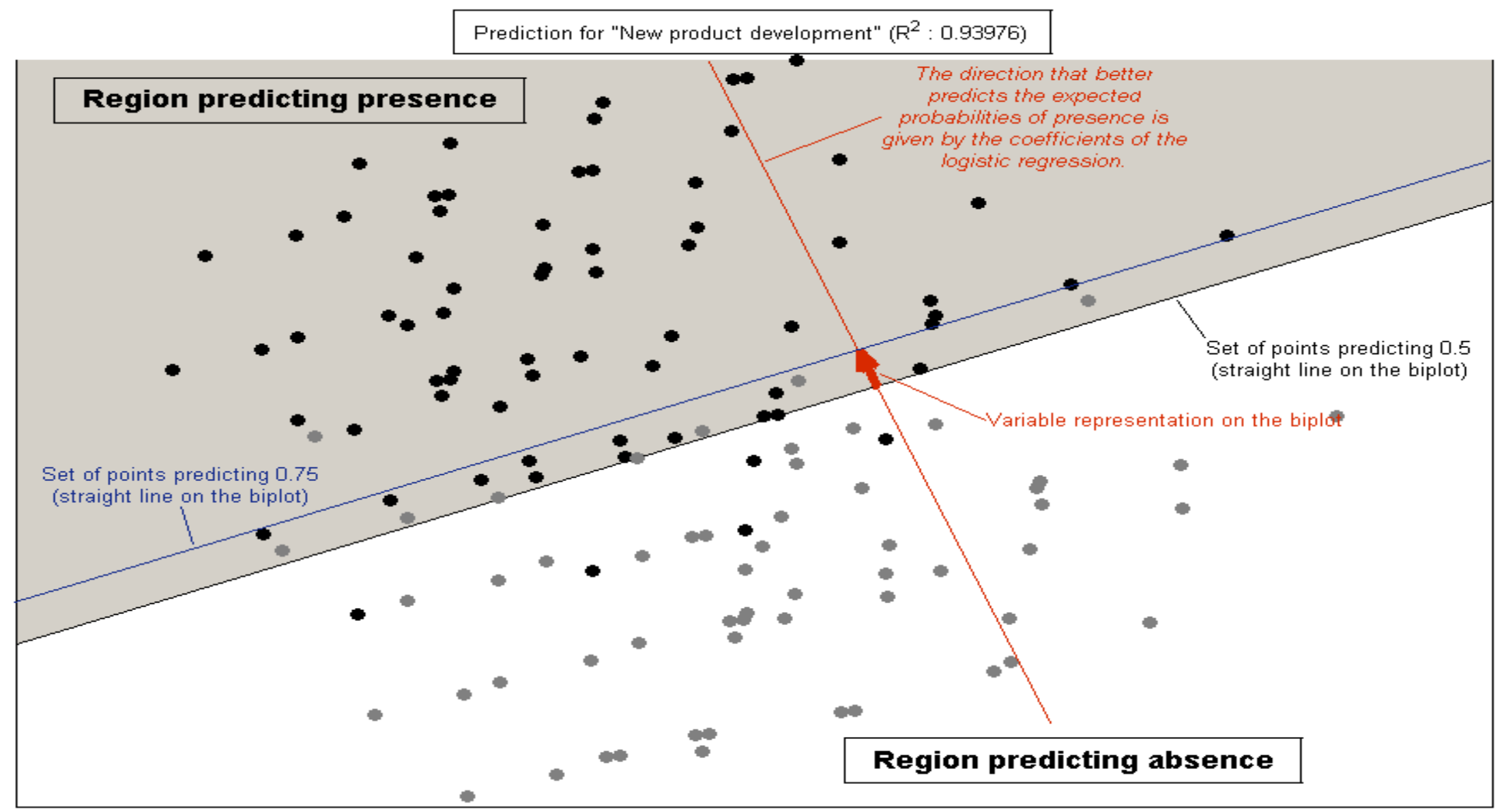

The dark circles are the entities with observed presence and the light ones the entities with observed absence. Note that most of the observed presences are on the region predicting presence, while most of the observed absences are on the region predicting absence and that the wrong predictions have expected probabilities close to 0.5 . That means that the variable is correctly summarized on the graph, as shown also by high values of the quality of representation indexes $\left(R^{2}=0.94, p<0.00001\right.$, percentage of correct classification $=97.27$ per cent) 